\title{
GENE FREQUENCIES IN WILD POPULATIONS OF TRIFOLIUM REPENS
}

\section{DISTRIBUTION BY LATITUDE}

\author{
HUNOR DADAY \\ Welsh Plant Breeding Station, Aberystwyth*
}

Received I 5.vi.53

\section{INTRODUCTION}

THE presence of hydrocyanic acid (HCN) in Trifolium repens L. has been realised for some time (Mirande, 1912). The plants possess cyanogenetic glucosides consisting of 80 per cent. lotaustralin and 20 per cent. linamarin (Melville and Doak, 1940) and the term glucoside is used in this paper to denote these cyanogenetic glucosides. The enzyme linamarase hydrolyses the glucoside into its components with the production of HCN.

Research has been carried out on hydrocyanic acid in T. repens, from three points of view : its amount in the plants (Doak, I933; Rigg et al., I933 ; and Askew, 1933); its significance in seed certification (Foy and Hyde, 1937); and its possible role in contributing to bloat in ruminants (Evans and Evans, 1948). Further investigations have been concerned with the isolation of the glucoside (Melville and Doak, r940), and of the enzyme (Coop, r940) and their inheritance (Williams, I939; Corkill, I942; Atwood and Sullivan, 1943). Genetical studies (Corkill, I942; Atwood and Sullivan, 1943) have shown that two independent genes determine the production of the glucoside $A c-a c$, and enzyme Li-li. T. repens plants bearing both dominant genes crossed with the double recessive, gave a normal dihybrid segregation in $\mathrm{F}_{2}$.

Previous unpublished studies made by the late R. D. Williams had shown that the percentage of cyanogenetic plants varied from o-Ioo in populations of different geographical origin. The purpose of the present investigation was to determine the gene frequency in wild populations and to relate it to environmental factors. The four phenotypes :

(I) Glucoside and enzyme (AcLi)

(2) Glucoside only (Acli)

(3) Enzyme only (acLi)

(4) Neither glucoside nor enzyme (acli)

were distinguished by the picric acid test, using isolated lotaustralin and linamarase solutions as described by Corkill (1940). This technique, however, was modified by retesting the plants provisionally classified as the Acli phenotype with a solution of isolated lotaustralin

* New address Division of Plant Industry, Canberra, Australia. 
to detect small amounts of enzyme, as will be described in a later paper. The Hardy-Weinberg formula $\left(p^{2}+2 p q+q^{2}=1\right)$ was applied to determine the genotypic frequencies of the populations (Hardy, I908; Weinberg, I908).

A collection of wild $T$. repens seeds was made from most European and some Near Eastern countries. This collection was made possible by the kind co-operation of the British Council, Agricultural Experimental Stations, Universities and Agricultural Ministries in the countries concerned. They were requested to adhere to the following conditions of seed collection : 20 wild $T$. repens seed heads to be collected from five different ecological areas around the named locality or " collection centre" ; the collection to be of wild $\mathcal{T}$. repens only, and the place of collection to be well isolated from any cultivated land or reseeded pasture.

\section{WILD T. REPENS POPULATIONS}

Wild T. repens is widely distributed in Europe and Asia, where it can be found in pastures, meadows, on road sides, river banks, etc. Kousnetzoff (1926) has suggested that $\mathcal{T}$. repens and most of the other Trifolium species have their centre of origin in the Mediterranean region. Wild $T$. repens has spread throughout Europe, as far as the Lake Baikal region on the mainland of Asia and to Japan and Ceylon, growing at altitudes up to $2200-2300 \mathrm{~m}$. above sea level in the Alps and probably up to the same altitude in other mountain regions. $\mathcal{T}$. repens is not known to have been indigenous outside the Old World.

\section{The genetical structure of European and Near Eastern populations}

The phenotypic structure of populations can be expressed by the percentage frequency of the four phenotypes (AcLi, Acli, acLi and acli) and these are set out in Appendix I. Considerable variation exists between populations in regard to their phenotypic proportions. Heterogeneity tests, using $2 \times 2$ contingency tables, were made to determine whether any differences existed between the phenotype frequency in samples from different geographical regions, and for this purpose the four phenotypes were grouped into two as follows : (a) AcLi phenotype ; (b) Acli, acLi and acli phenotypes.

An analysis of the population samples from geographical regions shows that the Mediterranean populations possess the highest frequency of $A c L i$ phenotype. In Greece (Athens), for example, the frequency is Ioo per cent., and in Israel (Huleh District), Italy (Lucca), Spain (La Coruña) the Acli and acli phenotypes occur only occasionally. Samples from northern Italy (San Daniele del Friuli, Milan), however, differ markedly from the above populations, the majority of the plants being of the acli type. In some of the populations from Ireland (Longford), Great Britain (Aberystwyth), France (Finistère), two to 
four phenotypes are found, but in all cases the $A c L i$ type predominates. The decrease in the frequency of the $A c L i$ phenotype from the Mediterranean region to France is significant (heterogeneity $x^{2}=\mathrm{II} \cdot 62$, $\mathbf{P}<0 \cdot 001$ ), as is also the decrease in frequency from France to Great Britain $\left(x^{2}=14 \cdot 72, \mathrm{P}<0 \cdot 001\right)$. All four phenotypes are represented in most of the German and Swiss populations (Hohenheim, Lausanne, Zürich), but the $A c L i$ phenotype decreases in favour of the $A c l i, a c L i$ and acli phenotypes; the difference between the British and German populations is so obvious as to require no statistical proof. A Dutch

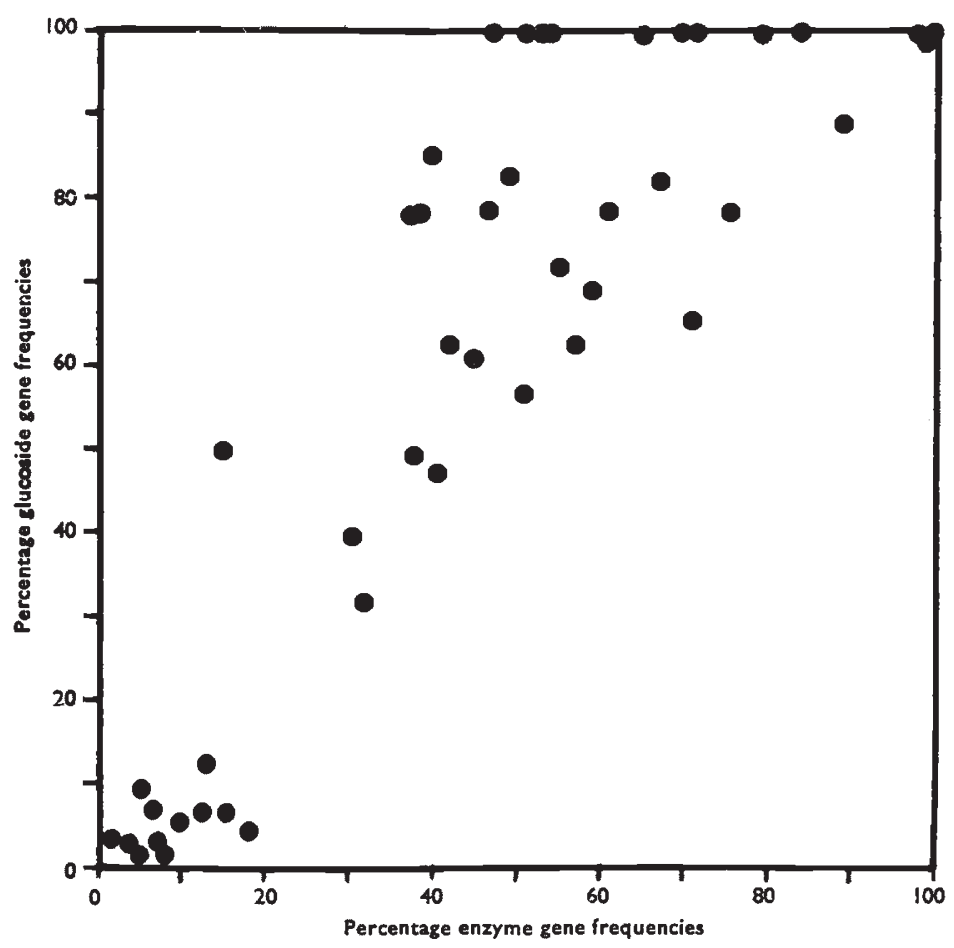

Fig. 1.-Frequencies of the dominant glucoside lotaustralin $(A C)$ and enzyme linamarase (Li) genes in European and Near Eastern wild populations of Trifolium repens.

sample (Breda) shows approximately equal proportions of the four phenotypes. The trend continues in Denmark (North Jutland), Germany (Hanover, Straubing), Austria (Rupprechtshofen), Nethe1lands (Groningen), where the acli phenotype becomes predominant. Marked trends are also noticeable in other central, eastern, and northern European samples. From the analyses it appears that the frequency of the acli phenotype reaches a maximum in Norwegian (Tjøtta), Hungarian (Budapest), and Polish (Kościan) samples. Unpublished data of R. D. Williams on Swedish and Russian populations indicate the existence of populations consisting entirely of acynanogenetic plants. 
Genotypic structure.-In the investigation of the genotypic structure of populations, the proportion of dominant homozygous $\left(p^{2}\right)$, heterozygous $(2 p q)$ and recessive homozygous $\left(q^{2}\right)$ genotypes was determined by the Hardy-Weinberg formula. The genotypic frequencies of glucoside $(A c-a c)$ and enzyme genes $(L i-l i)$ are presented in Appendix 2.

When the glucoside and enzyme gene frequencies are plotted against one another (fig. I) they show a gradation from very low values to extremely high values. As will be seen later, moreover, this gradation forms a close parallel with the geographical origin ranging from the low values for north-eastern Europe to the high values for the Mediterranean region.

\section{RELATION OF GENE FREQUENCY TO THE ENVIRONMENTAL FACTORS}

Marked differences have been found to occur in the genetical structure of wild $T$. repens populations from different regions in Europe and the Near East. In view of the progressive increase in the frequency of recessive genes in moving from south to north-east Europe, an attempt has been made to correlate this with environmental factors.

No correlation can be discerned between the gene frequency of populations and the rainfall of the regions in which they exist, the annual isotherms, or the July isotherm. However, it was noted that the January isotherms were very closely correlated with the gene frequency distribution. Fig. 2 shows the distribution and frequency of the glucoside gene in wild $T$. repens populations superimposed on the January isotherms in Europe and the Near East. The $46 \cdot 3^{\circ} \mathrm{F}$. isotherm passes through Spain, Italy, Greece and Turkey. In all samples which originated from regions near to, or on the warm side of this line, the dominant gene frequency is, in general, high. The proportion of the plants bearing the glucoside gene in the populations averages 94.8 per cent., though it reaches roo per cent. in many cases. In the region between the $46 \cdot 3^{\circ}$ to $40 \cdot 0^{\circ} \mathrm{F}$. isotherms, while some samples of $\mathcal{T}$. repens still show very high frequencies of the dominant gene, the greater number of the populations show an increase in the frequency of the recessive gene, ranging from $o$ to 37.4 per cent. This area includes Great Britain, Ireland, the west and south coast of France and the northern part of Turkey. Only a few seed samples were collected in the next temperature belt from the $40^{\circ} \mathrm{O}$ to $35^{\circ} 6^{\circ} \mathrm{F}$. isotherms. These $T$. repens populations still have a high degree of dominant gene frequency. From the $35^{\cdot 6}$ to $32.0^{\circ} \mathrm{F}$. lines, there is a marked change in the gene frequency pattern. A large number of samples from the Netherlands, Belgium, Germany, Switzerland, Liechtenstein and Denmark were tested and gave ample evidence of this trend towards a high rate of change in the gene frequency structure between these two isotherms. Investigations of 
the gene frequency of Belgian and Dutch wild material show a continuous reduction in dominant gene frequency from Brussels $\left(4^{6} \cdot 7\right.$ per cent.), through Breda ( $3{ }^{\mathrm{I}} \cdot 6$ per cent.), to Groningen ( $9 \cdot 3$ per cent.). A similar pattern is apparent between these two isotherms in Switzerland and Liechtenstein (Lausanne, 62.4 per cent. ; Zürich,

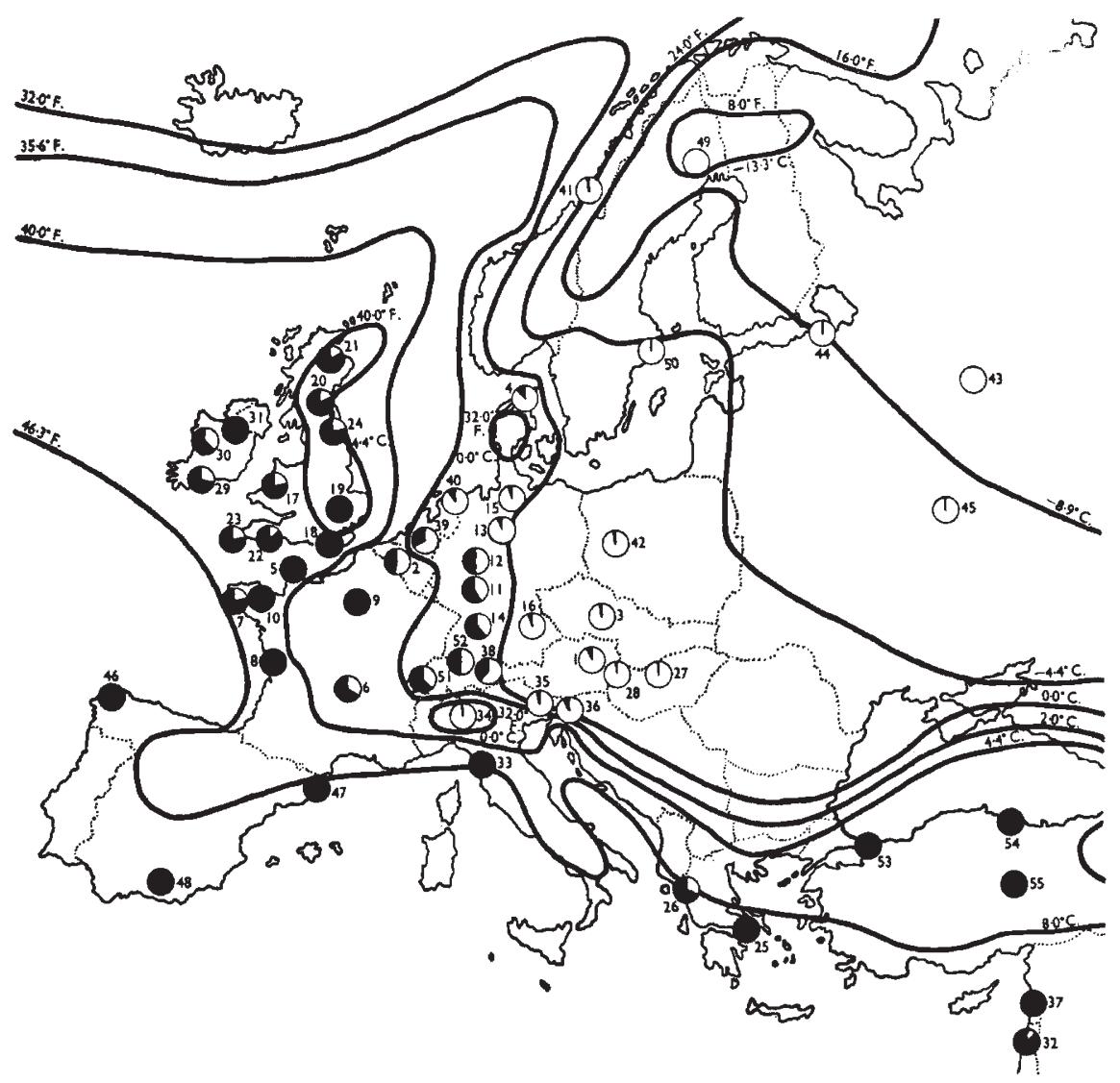

Fig. 2.-Distribution and frequency of the glucoside lotaustralin gene in European and Near Eastern wild populations of Trifolium repens L.

Black section : Dominant gene frequency.

White section : Recessive gene frequency.

- January isotherm (refer to the Appendix $\mathrm{I}$ for the location numbers on the map).

49.4 per cent. ; Schaanwald, 39.4 per cent.). Striking variations were noted in the gene frequency of German populations. The three west German samples possess a high proportion of dominant genes (Hohenheim, 6r $\cdot 8$ per cent. ; Frankfurt a/M, $57 \cdot 7$ per cent. ; Giessen, $50^{\circ} \circ$ per cent.), while the other two samples from locations very near the $32 \cdot 0^{\circ} \mathrm{F}$. isotherm have low dominant gene frequencies (Hanover, 6.4 per cent. ; Schessel, 4.3 per cent.). After crossing the $32 \cdot 0^{\circ} \mathrm{F}$. 
isotherm the proportion of dominant genes in wild $T$. repens continues to decrease. This process, however, is much less pronounced (Germany, Straubing, 4.8 per cent. ; Austria, Rupprechtshofen, 6.5 per cent. ; Hungary, Budapest, $\mathrm{I} \cdot 2$ per cent.), than in the previous temperature belt. The $32 \cdot 0^{\circ} \mathrm{F}$. January isotherm occurs in the Po Valley in-

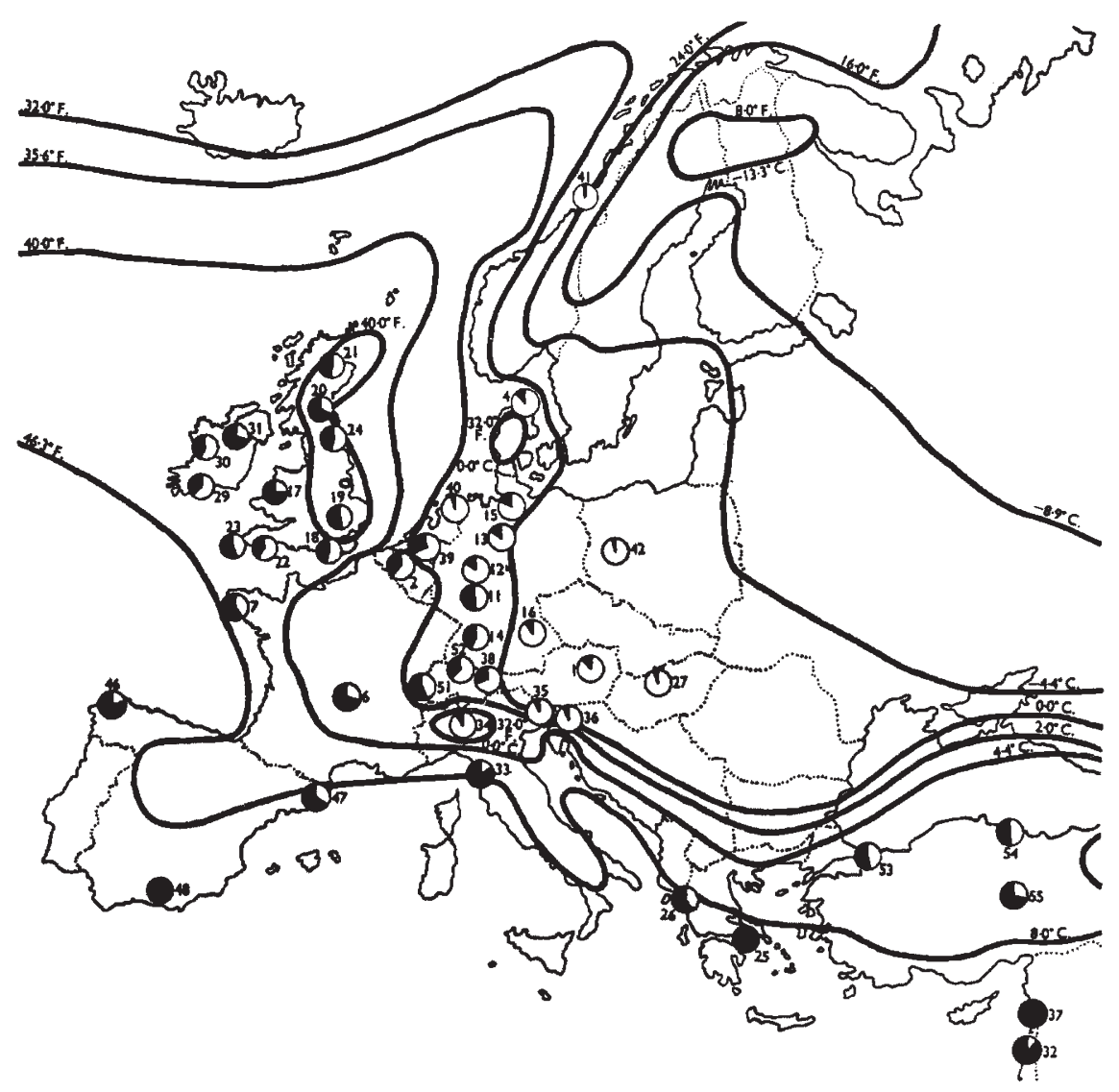

FrG. 3.-Distribution and frequency of the enzyme linamarase gene in European and Near Eastern wild populations of Trifolium repens $\mathrm{L}$.

Black section : Dominant gene frequency.

White section : Recessive gene frequency.

- January isotherm (refer to the Appendix I for the location numbers on the map).

dependently of the main isotherms across Europe. This low winter temperature seems to explain why the wild populations of the Po Valley and a cultivated strain of Ladino white clover have low percentages of dominant genes and in this respect resemble samples obtained from below the $32.0^{\circ} \mathrm{F}$. line in central Europe. The lowest dominant glucoside gene frequency occurs below the $16 \cdot 0^{\circ} \mathrm{F}$. isotherm. No samples were obtained from Russia and Sweden for this present 
investigation and the data presented have been taken from the unpublished data of R. D. Williams. According to the results of this previous investigation, in two samples out of four, cyanogenetic plants occur, but the gene frequency is reduced to very low values (U.S.S.R., Leningrad, $1 \cdot 2$ per cent., Orel, 0.4 per cent.). No plants with double dominant genes were found in populations from northern and eastern Europe, including Sweden (Luleå) and U.S.S.R. (Jaroslavl). A similar genetical pattern can be established in the case of the geographical distribution of the enzyme gene frequency which is illustrated in fig. 3 .

The variation in the occurrence of the dominant enzyme gene is much more pronounced than that for the glucoside gene above the $40.0^{\circ} \mathrm{F}$. isotherm. In the course of the investigation, populations were found with $37^{\circ} 9$ to roo per cent. dominant gene frequencies. The frequency of occurrence of the recessive gene was greater in Great Britain, Ireland and Turkey than in samples from the rest of the region above the $40^{\circ} 0^{\circ} \mathrm{F}$. isotherm. In a manner similar to that of the glucoside gene, the enzyme gene composition of populations continues to alter along, and on the colder side of, the $35^{\circ} 6^{\circ} \mathrm{F}$. isotherm. From the data relating to the dominant enzyme gene proportions, a rapid reduction towards the $32.0^{\circ} \mathrm{F}$. isotherm in Belgian, Dutch, Swiss, Liechtenstein, German and Danish samples is apparent, and this conforms closely with similar reductions found in the proportions of the glucoside gene. Due to the fact that only a limited number of samples were available from the eastern half of Europe, no tests could be carried out on populations outside the $24^{\circ} 0^{\circ} \mathrm{F}$. isotherms. Samples obtained from between the $32.0^{\circ} \mathrm{F}$. and $24^{\circ} 0^{\circ} \mathrm{F}$. isotherms have been shown to maintain the previous trend in the reduction of the dominant enzyme gene frequency and in being closely correlated with decreasing mean winter temperature.

Fig. 4 compares the mean glucoside and enzyme gene frequency of populations originating from regions between different January isotherms. It establishes a reduction in dominant allele frequencies in the successive zones, from high to low temperatures. In zones $\mathbf{I}$, II and III the glucoside gene is more common than the enzyme gene. This is reversed in zone IV, where the mean frequency of the enzyme gene is more than twice as high as that of the glucoside gene. No reliable data were available concerning the enzyme gene frequency in zone $\mathrm{V}$, although a greater frequency of this gene than the corresponding glucoside gene frequency is indicated by the regression coefficient.

In order to test the relationship of January temperature and the gene frequency the regression coefficient was calculated. The $t$ test showed that both of the obtained values were highly significant, being $t_{(44)}=9.00$ in the case of the glucoside gene frequency and $t_{(44)}=8.98$ in the case of the enzyme gene ( $P$ in both cases less than $0 \cdot 001$ ). Both coefficients are highly significant, which demonstrates 
that a close relationship exists between decreasing dominant gene frequencies and decreasing January mean temperatures. From the analyses, it was also apparent that the dominant glucoside gene frequency decreases by 4.23 and the enzyme gene frequency by 3.16 per cent. for each reduction of $\mathrm{r}^{\circ} \mathrm{F}$. $\left(0.55^{\circ} \mathrm{C}\right.$.) January mean temperature. It is also of interest to consider whether the respective rates of decrease in glucoside and enzyme gene frequencies differ. From the analysis of variance of the decreases of the two gene frequencies it appears that the difference between the two regression

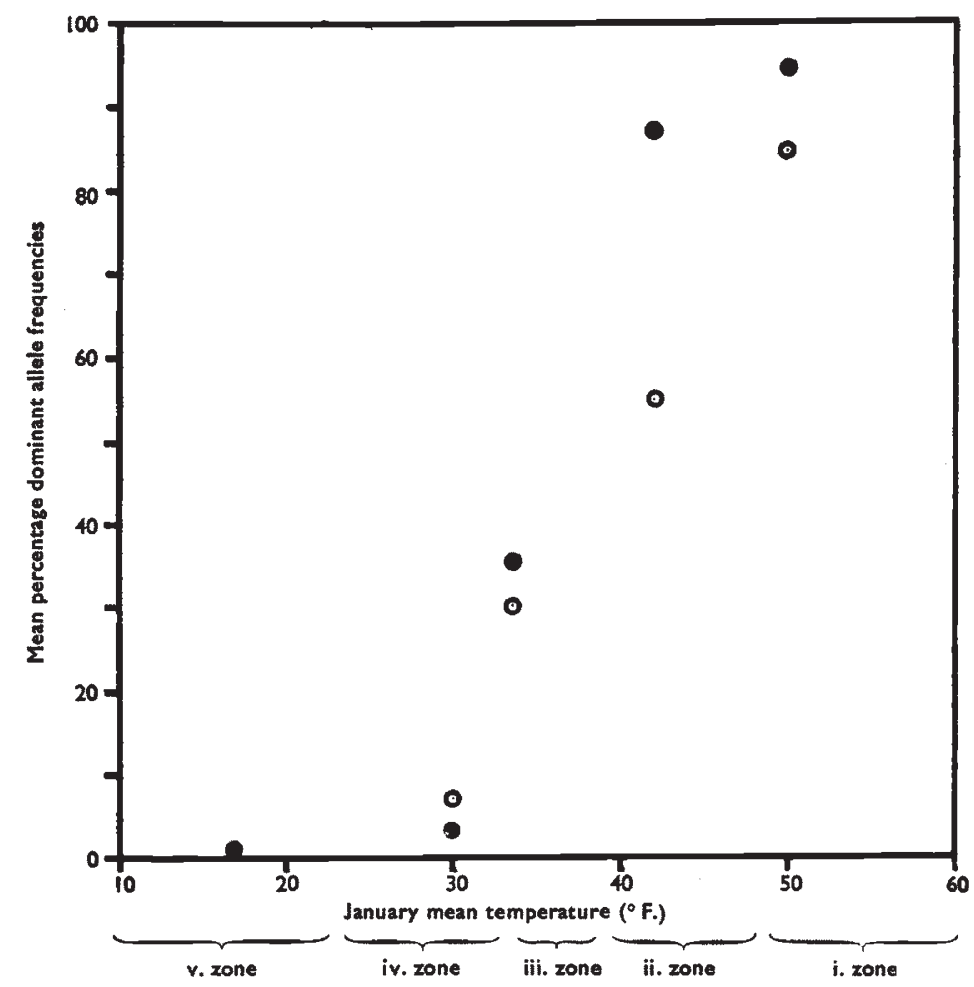

Fig. 4.-Mean frequencies of the glucoside lotaustralin $(A c)$ and enzyme linamarase $(L i)$ alleles in different January temperature zones. $(\odot=$ glucoside allele ; $\odot=$ enzyme allele.)

coefficients is significant $\left(t_{(88)}=2 \cdot 206\right.$ with a probability of between $0 \cdot 05-0 \cdot 02$ ), which suggests that the glucoside gene frequency decreases by a significantly greater amount than does the enzyme gene frequency.

\section{GEOGRAPHICAL VARIATION AND EVOLUTION}

Several authors have discussed the problem of geographical divergence, especially in human and animal populations. Boyd (1939) and Lundman (1948) studied the geographical distribution and frequency of the blood groups in man. Crampton (1916, 1932) 
showed the variation of the dextral and sinistral spirals of Partula suturalis vexillum. The frequency of white females in the orange race of Colias chrysotheme (= eurytheme) showed a change from 74 per cent. in the North San Joaquin Valley to I3 per cent. in the Imperial Valley (Hovanitz, I944). Dobzhansky (1939, I944) found differences in the incidence of gene arrangements in the third chromosome among populations of Drosophila pseudoobscura and Drosophila persimilis derived from what was presumably a continuously inhabited region.

The investigations strongly indicate that geographical factors (climate, solar intensity, day-length, etc.) generally play an important role in geographical speciation. It has also been shown that organisms are able to adapt themselves to environmental gradients (e.g. latitude, altitude, temperature, etc.) and that natural selection moulds the character of corresponding adaptive clines. This relationship between organisms and their environments is expressed in the rules of Bergmann, Allen and Gloger (Goldschmidt, I940). These state that there is a definite correlation between body size or pigmentation increases and geographical gradients. Bergmann's rule states that the body size of warm-blooded animals usually increases with decrease in temperature.

Beside the morphological characters, it became evident that the physiological character of species is also subjected to adaptive selection. Timoféeff-Ressovsky (I935) showed in his investigation that Drosophila funebris populations derived from western Europe are especially susceptible to both extremes of temperature ; the Russian and Siberian ones are particularly resistant, while $D$. funebris from the Mediterranean region is susceptible to cold, but resistant to heat. The investigation of the gene frequency in $T$. repens populations also shows the occurrence of gene frequency clines. The samples of Mediterranean origin possess the highest frequency of dominant glucoside and enzyme genes. A continuous decrease of the dominant gene frequency takes place in western and central Europe, the proportions becoming extremely low and even absent in north eastern Europe. The distribution of the frequency of both chemical characters, the presence or absence of which is governed by these two genes, shows an outstanding correlation with the January isotherms. From this it is apparent that these clines are caused by a geographical factor acting upon European wild $T$. repens populations, resulting in a gene frequency pattern ranging from a high dominant gene frequency to a very low one, depending on the factor pressure prevailing.

The picric acid test provides a means of assessing the amount of glucoside present (Melville et al., I940), as well as its frequency in the population sample. In Mediterranean samples the fresh leaves were found to contain a high proportion of $\mathrm{HCN}$ (more than 0.02 per cent.) whereas a large proportion of the northern European glucosidecontaining plants produced very little $\mathrm{HCN}$ (0.006-0.02 per cent.). 
Such quantitative differences are regarded as being due to the effects of modifying genes (Williams, r 939). Differences also occur in the quantity of enzyme produced. The large proportion of plants in the northern regions with a low output of gene products is probably due to natural selection.

Although no other characters were closely studied in this investigation, several observations indicate variability in other factors in the species. The leaf of $T$. repens usually bears a white marking. It is known that the presence of this character is governed by a single dominant gene (Atwood and Sullivan, 1943), the recessive allele producing no leaf mark. On the basis of a preliminary selection it was possible to distinguish six differently shaped leaf marks. Nearly every plant of Mediterranean $T$. repens has a leaf mark. All six shapes appeared and they were clearly marked on the leaf. The dominant gene was still abundantly evident in central Europe, but the recessive type was found to be more frequent than in the previous region and the leaf mark shape was less pronounced. The Norwegian population contained an increased proportion of the recessive type, with a very faint mark and little variation in shape. Further genetical research is necessary, particularly with regard to the genetical relationship between leaf mark types, before this character can be used in determining geographical gene frequency.

Comparisons of the length of the corolla tubes also disclose marked differences. The Mediterranean $T$. repens appeared to possess uniformly long corolla tubes. In contrast, the Norwegian type has a short corolla tube. T. repens is a highly self-sterile species and is generally pollinated by bees. This relationship between the plant and the bee makes an investigation by Alpatov (1929) particularly interesting. He studied the tongue length range of the honey bee in the plain of European Russia. Alpatov found the shortest tongue length in the northern bee populations and that the tongue length gradually increased in populations, as their origin moved southwards. If in T. repens populations the corolla tubes were found similarly to vary in size, i.e. gradually increasing in length from the shortest in the north to the longest type in the south, such evidence would be of considerable interest and importance, both biologically and practically.

Further differentiation can be mentioned in respect of habit of growth and flowering time. Generally speaking, the southern European T. repens appears as an erect type, with large leaves, thick stems and early flowering; the northern European (Norwegian) type, on the other hand, is prostrate with smaller leaves, thinner stems and is late flowering.

Apart from the larger and more general character clines that have been discussed, wild $T$. repens can be divided into several ecotypes, each possessing features adapted to local microgeographical conditions. Previous investigators of geographical variation in the hereditable 
characters of species have attributed this variation to genetical drift, adaptive selection, migration, isolation, etc.

Before considering the evolutionary mechanism of gene frequency variation in wild $T$. repens populations, the correlation between the decreasing winter temperature and the parallel increasing proportion of recessive genes should be stressed. Modern evolutionary views suggest that only a very low rate of mutation occurrence can be expected, while the importance of natural selection in the case of adaptive geographical variation has been pointed out. In the light of these modern theories, it can be expected that however the recessive mutant type arises in $T$. repens populations, the rate of frequency should be rather low. Because of the adaptive advantage of the carrier of the mutant gene under natural selection, the winter temperature pressure was an effective factor in the case of the widely distributed species $T$. repens. The process of change in the genetic structure of the species presumably continued until an equilibrium was reached between the selection pressure and the proportion of genotypes in T. repens in given regions. It is interesting to note that the selection pressure resulted in similar gene frequency clines for both glucoside and enzyme genes. However, the extent of the reaction to the selection pressure was not in all cases the same. In the warmer January temperature zones (zones I, II and III), a larger proportion of mutant recessive enzyme than glucoside genes was brought forward by the selection pressure; by contrast, in zone IV, the recessive glucoside gene showed a significantly greater frequency, compared with the recessive enzyme genes, giving a balance between the gene frequency composition and the environmental gradient.

Further studies of different character clines in the species may reveal other progressive variation clines. The plastic nature of species makes the existence of other such character clines quite probable. These clines may show correlation with some geographical factor other than January isotherms, such as latitude.

The unpublished work of R. D. Williams was concerned with the determination of cyanogenetic plant proportions which correspond to $A c L i$ phenotype. His method does not disclose the Acli and $a c L i$ phenotypes and it is therefore not suitable for the purpose of gene frequency calculations. Because no seed samples from Czechoslovakia, Russia and Sweden became available in time for the present investigation, the data of R. D. Williams were used for calculating purposes. Owing to the extremely low gene frequency, the limitation of the test can be neglected.

It may be concluded from the investigation, that in the wild $T$. repens populations there exists a gene frequency cline which is conditioned by the winter temperature prevailing, and that geographical speciation has given rise to several subspecies of wild $T$. repens in Europe and the Near East. 


\section{SUMMARY}

I. The phenotypic and genotypic structures of wild Trifolium repens populations were investigated. By means of a modified picric acid test, $T$. repens plants were classified into four phenotypes (I) Glucoside and enzyme (AcLi) ; (2) Glucoside only (Acli) ; (3) Enzyme only $(a c L i)$ and (4) neither glucoside nor enzyme (acli) according to the presence of glucoside lotaustralin $(A c-a c)$ and enzyme linamarase ( $\mathrm{L} i$-li) genes in dominant or recessive conditions. The genotypic structure was determined by the Hardy-Weinberg formula

$$
\left(p^{2}+2 p q+q^{2}=\mathrm{I}\right) \text {. }
$$

2. There was a continuous gradual decrease in the frequencies. of glucoside lotaustralin and enzyme linamarase genes over the whole range from Ioo to o per cent. as the source of the samples of wild $T$. repens populations moved from the Mediterranean region to northeastern Europe.

3. The distribution of the dominant allele frequencies in the populations was closely correlated with the January isotherms.

4. A decrease of $\mathrm{I}^{\circ} \mathrm{F}$. in January mean temperature resulted in a reduction of 4.23 per cent. in the frequency of the glucoside gene, and a reduction of $3 \cdot 16$ per cent. in the frequency of the enzyme gene.

5. Thus January temperatures have played an important role through natural selection in the evolution of subspecies in $T$. repens.

Acknowledgments.-I am greatly indebted to Professors T. J. Jenkin and E. T. Jones, the former and present Directors of the Welsh Plant Breeding Station for facilities to carry out the investigation. It is a pleasure to acknowledge the helpfulness of Mr A. G. G. Hill, Director of the Commonwealth Bureau of Pastures and Field Crops, and the British Council, in organising the seed collection, and to all collectors from European and Near Eastern countries who contributed greatly by sending the seed samples :-

Austria : Dr H. Franz, Dr F. Pammer, Prof. Dr A. Zeller, Dr F. Zürn.

Belgium: Mr A. Lawalrée.

Denmark: Mr H. Frederiksen, Prof. A. Pedersen.

France : Prof. P. Bugnon, Mr A. Chevalier.

Germany : Prof. Dr E. Klapp, Dr F. König.

Great Britain: Messrs A. R. Beddows, W. E. G. Bolt, A. W. R. Brown, S. P. Craze, K. A. Dowell, A. J. Heard, T. D. Holmes, G. R. Lewis, H. Mead,

Mrs E. B. Owen, Miss M. E. Owen, Messrs J. N. R. Thomas, R. Wight.

Greece : Mr P. D. Critopoulos.

Hungary: Mrs Dr L. Daday, Dr I. István.

Ireland: Prof. M. Caffrey.

Israel : Messrs Y. Carmon, A. Hamelburg.

Italy: Prof. E. Zanini.

Jugoslavia : Prof. Ferlino.

Netherlands : Messrs G. Mulder, J. M. Schijen, A. Thorenaar.

Norway: Mr M. Jetne.

Poland: Miss Dr M. Falkowski, Prof. W. Szafer.

Spain: Messrs R. Escauriaza, F. R. Bellot, E. Vieitez.

Switzerland : Dr J. Caputa, Dr A. Kauter.

Turkey: Messrs M. Akdogan, N. Ergintan, G. Feshel. 
The author also wishes to thank Professor P. T. Thomas, Department of Agricultural Botany, University College of Wales, for his interest and advice in the work, and Dr A. Durrant, for his suggestions with regard to the statistical methods applied ; Messrs Watkin Williams and W. E. Davies, the former and present heads of the Clover Breeding Section of the Welsh Plant Breeding Station, for their suggestions and help ; the Edward Davies Chemical Laboratories, University College of Wales, for the preparation of the lotaustralin and linamarase; Mr P. J. Boyle for his help with the manuscript.

\section{REFERENCES}

ALPATOV, w. w. 1929. Biometrical studies on variation and races of the honey bee (Apis mellifera L.). Quart. Rev. Biol., 4I, I -58.

ASKEW, H. O. 1933. Determination of hydrocyanic acid in white clover. N.Z. F. Sci. Tech., ${ }^{5}, 227-233$.

ATWOOD, s. s., AND SULLIVAN, J. T. 1943. Inheritance of a cyanogenetic glucoside and its hydrolysing enzyme in Trifolium repens. 7. Hered., 34, 31 I-320.

BOYD, w. G. 1939. Blood groups. Tabul. biol. Berl., I7, I13-240.

COOP, I. E. 1940. Cyanogenesis in white clover (Trifolium repens L.) III. A study of linamarase, the enzyme which hydrolyses lotaustralin. N.Z. F. Sci. Tech., $22,7_{1} \mathrm{~B}-83 \mathrm{~B}$.

CORKILL, L. I940. Cyanogenesis in white clover (Trifolium repens L.). I. Cyanogenesis in single plants. $\mathcal{N} . Z$. F. Sci. Tech., $22,65 \mathrm{~B}-67 \mathrm{~B}$.

CORKILL, L. 1942. Cyanogenesis in white clover (Trifolium repens L.). V. The inheritance of cyanogenesis. N.Z. F. Sci. Tech., 23, 1 78B-193B.

GRAMPTON, H. E. I9I6. Studies on the variation, distribution, and evolution of the genus Partula. The species inhabiting Tahiti. Publ. Carneg. Instn., 228, I-3II.

CRAMPTON, H. E. 1932. Studies on the variation, distribution, and evolution of the genus Partula. The species inhabiting Moorea. Publ. Carneg. Instn., 4IO, I -335 .

DOAK, B. W. 1933. A chemical method for the determination of type in white clover. N.Z. F. Sci. Tech., 14, 359-365.

DOBZHANSKx, TH. 1939. Microgeographic variation in Drosophila pseudoobscura. P.N.A.S., 25, 311-314.

DoBzhansky, TH. 1944. Chromosomal races in Drosophila pseudoobscura and Drosophila persimilis. Publ. Carneg. Instn., 554, 47-144.

EVANS, E. T. R., AND EVANs, w. c. 1948. Studies on the biochemistry of pasture plants. 2. The pharmacological properties of certain pasture plant juices, and their possible significance in the ætiology of some disorders of the grazing animal. F. Brit. Grassl. Soc., 3, 249-26r.

FOY, N. R., AND HYDE, E. O. C. I937. Investigation of the reliability of the "Picric acid test" for distinguishing strains of white clover in New Zealand. N.Z.J. Agric., 55, 219-224.

hARDY, G. H. I908. Mendelian proportions in a mixed population. Science, 28, 49-50.

HOVANTIZ, w. 1944. The distribution of gene frequencies in wild populations of Colias. Genetics, 29, 31-60.

Goldschmid, R. 1940. The Material Basis of Evolution. New Haven, Yale University Press.

KOUSNETZOFF, v. A. 1926. Areas of the geographical distribution of the most important forage species of clover and alfalfa. Bull. Appl. Bot. Leningrad, $r 6$, 55-88.

LUNDMAN, B. 1948. Geography of human blood groups (A, B, O system). Evolution, $2,231-237$.

[Continued on p. 78 . 


\section{APPENDIX I}

Frequency of the four phenotypes in European and Near Eastern wild populations of Trifolium repens (per cent.)

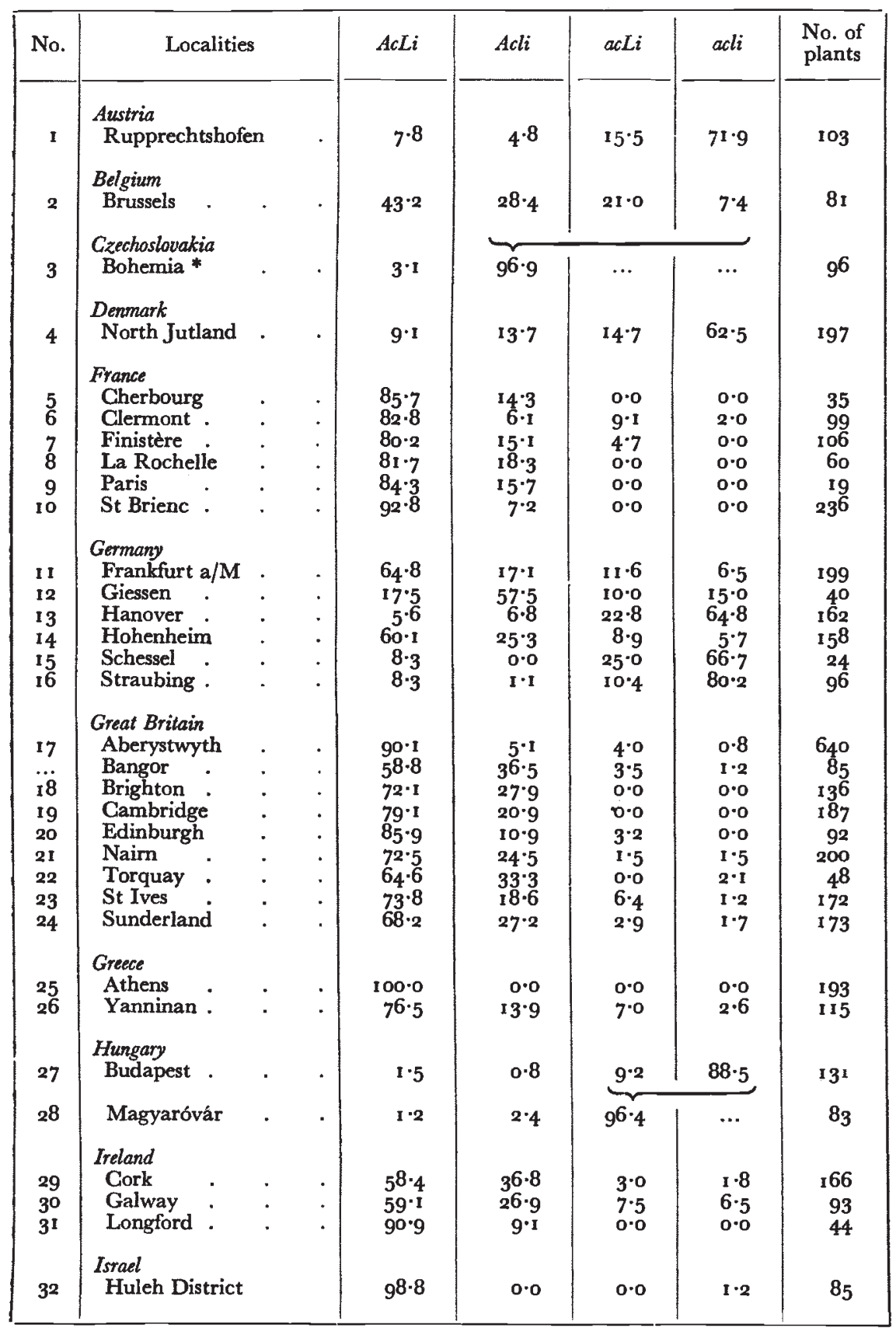


APPENDIX I-continued

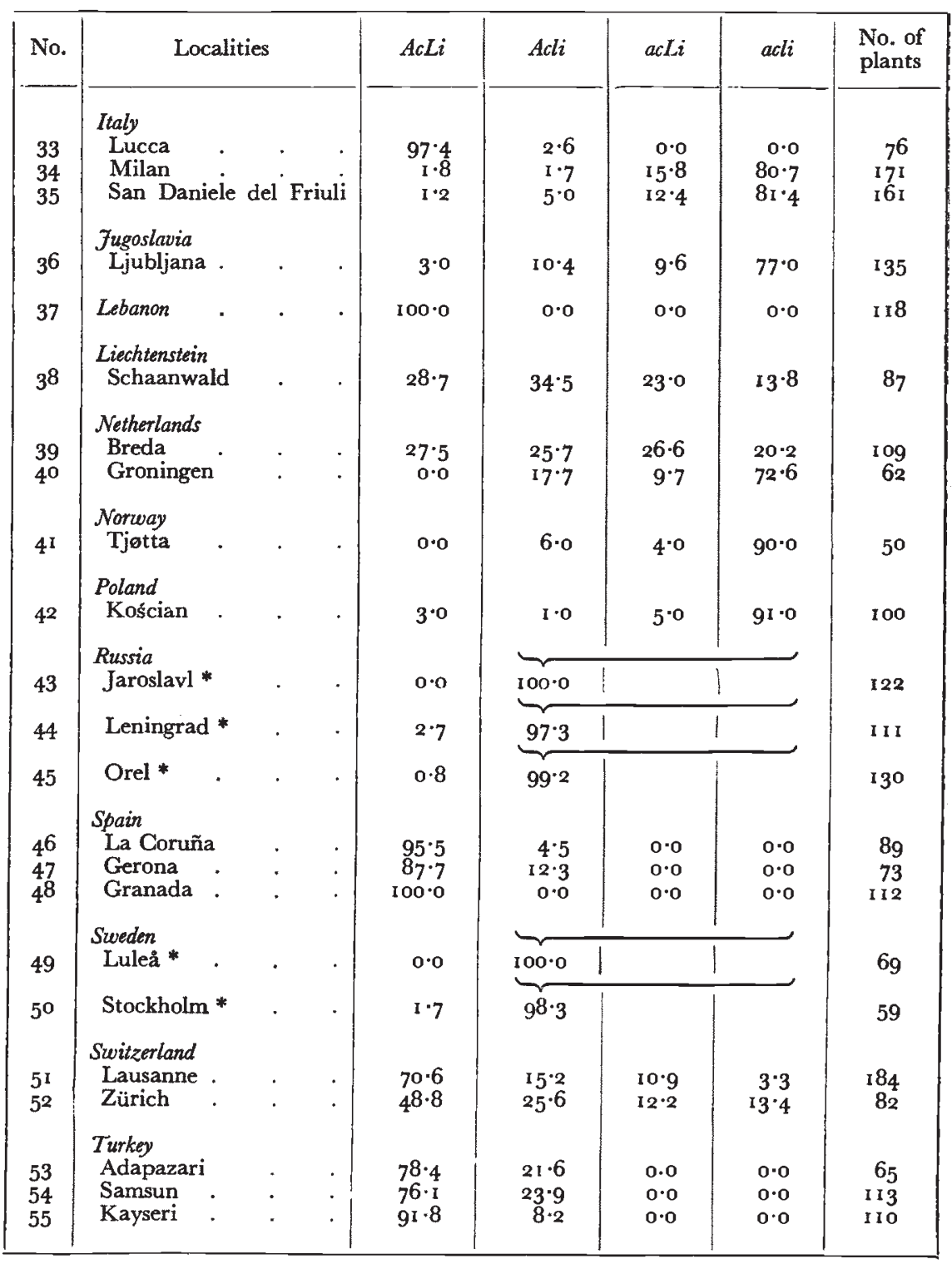

* From the unpublished data of the late R. D. Williams. 


\section{APPENDIX II}

Frequency of the glucoside and enzyme genotypes in European and Near Eastern wild populations of Trifolium repens

\begin{tabular}{|c|c|c|c|c|c|c|c|c|}
\hline \multirow{2}{*}{\multicolumn{2}{|c|}{ Localities }} & & \multicolumn{3}{|c|}{ Glucoside genotypes } & \multicolumn{3}{|c|}{ Enzyme genotypes } \\
\hline & & & $p^{2}$ & $2 p q$ & $q^{2}$ & $p^{2}$ & $2 p q$ & $q^{2}$ \\
\hline & & & $A c A c$ & Acac & $a c a c$ & $\mathrm{LiLi}$ & Lili & lili \\
\hline \multicolumn{9}{|l|}{ Austria } \\
\hline Rupprechtsho & fen & . & 0.004 & $0 \cdot 122$ & $0 \cdot 374$ & 0.015 & 0.218 & 0.767 \\
\hline \multicolumn{3}{|l|}{ Belgium } & 0.218 & 0.498 & $0 \cdot 284$ & $0 \cdot 162$ & 0.480 & $0 \cdot 35^{8}$ \\
\hline \multicolumn{6}{|l|}{ Denmark } & 0.016 & 0.222 & 0.762 \\
\hline \multicolumn{9}{|l|}{ France } \\
\hline Cherbourg & . & . & $i \cdot 000$ & 0.000 & 0.000 & $\ldots$ & $\ldots$ & $\cdots$ \\
\hline Clermont & . & . & 0.445 & 0.444 & 0.111 & 0.512 & 0.407 & $0.08 \mathrm{r}$ \\
\hline Finistère & . & . & 0.613 & 0.340 & 0.047 & 0.374 & 0.475 & 0.151 \\
\hline La Rochelle & . & . & $1 \cdot 000$ & 0.000 & 0.000 & $\ldots$ & $\ldots$ & $\ldots$ \\
\hline Paris . & . & . & $1 \cdot 000$ & 0.000 & 0.000 & $\ldots$ & $\ldots$ & $\ldots$ \\
\hline St Brienc & . & . & $1 \cdot 000$ & 0.000 & 0.000 & ... & ... & $\cdots$ \\
\hline \multicolumn{9}{|l|}{ Germany } \\
\hline Frankfurt a/A & & . & $0.33^{1}$ & $0 \cdot 4^{88}$ & $0 \cdot 181$ & 0.264 & 0.500 & 0.236 \\
\hline Giessen . & . & . & 0.250 & 0.500 & 0.250 & 0.022 & 0.253 & 0.725 \\
\hline Hanover & . & . & 0.004 & $0 \cdot 120$ & 0.876 & 0.024 & 0.260 & 0.716 \\
\hline Hohenheim & . & . & $0.3^{82}$ & 0.472 & 0.146 & $0 \cdot 197$ & 0.493 & 0.310 \\
\hline Schessel . & . & . & 0.001 & 0.082 & 0.917 & 0.033 & 0.300 & 0.667 \\
\hline Straubing & . & . & 0.002 & $0 \cdot 092$ & $0 \cdot 906$ & 0.010 & $0 \cdot 178$ & 0.812 \\
\hline \multicolumn{9}{|l|}{ Great Britain } \\
\hline Aberystwyth & . & . & 0.622 & $0 \cdot 33^{\circ}$ & 0.048 & 0.593 & 0.348 & 0.059 \\
\hline Bangor & . & . & 0.613 & 0.340 & 0.047 & $0 \cdot 149$ & 0.474 & 0.377 \\
\hline Brighton & . & . & $1 \cdot 000$ & 0.000 & 0.000 & 0.222 & 0.499 & 0.279 \\
\hline Cambridge & . & . & $1 \cdot 000$ & 0.000 & 0.000 & 0.295 & 0.496 & 0.209 \\
\hline Edinburgh & . & . & 0.671 & 0.296 & 0.033 & 0.449 & 0.442 & 0.109 \\
\hline Nairn . & . & . & 0.685 & 0.285 & 0.030 & 0.240 & 0.500 & 0.260 \\
\hline Torquay & . & . & 0.732 & 0.247 & 0.021 & $0 \cdot 164$ & 0.482 & 0.354 \\
\hline St Ives & . & . & 0.525 & 0.399 & 0.076 & 0.308 & 0.494 & $0.19^{8}$ \\
\hline Sunderland & . & . & 0.6 .6 & $0.33^{8}$ & 0.046 & 0.214 & 0.497 & 0.289 \\
\hline \multicolumn{9}{|l|}{ Greece } \\
\hline Athens . & . & . & 1.000 & 0.000 & 0.000 & $1 \cdot 000$ & 0.000 & 0.000 \\
\hline Yanninan & . & . & 0.477 & 0.427 & $0 \cdot 096$ & $0 \cdot 35^{2}$ & 0.483 & $0 \cdot 165$ \\
\hline \multicolumn{9}{|l|}{ Hungary } \\
\hline Budapest & . & . & 0.0001 & 0.0228 & $0.977^{1}$ & 0.003 & 0.104 & 0.893 \\
\hline \multicolumn{9}{|l|}{ Ireland } \\
\hline Cork . & . & . & 0.609 & 0.343 & 0.048 & $0 \cdot 144$ & 0.471 & 0.385 \\
\hline Galway : & . & . & 0.392 & 0.468 & 0.140 & 0.179 & 0.488 & 0.333 \\
\hline Longford & . & . & $1 \cdot 000$ & 0.000 & 0.000 & 0.488 & 0.421 & 0.091 \\
\hline $\begin{array}{l}\text { Israel } \\
\text { Huleh Distric }\end{array}$ & & . & $0 \cdot 794$ & $0 \cdot 194$ & 0.012 & $0 \cdot 794$ & $0 \cdot 194$ & 0.012 \\
\hline
\end{tabular}


APPENDIX II-continued

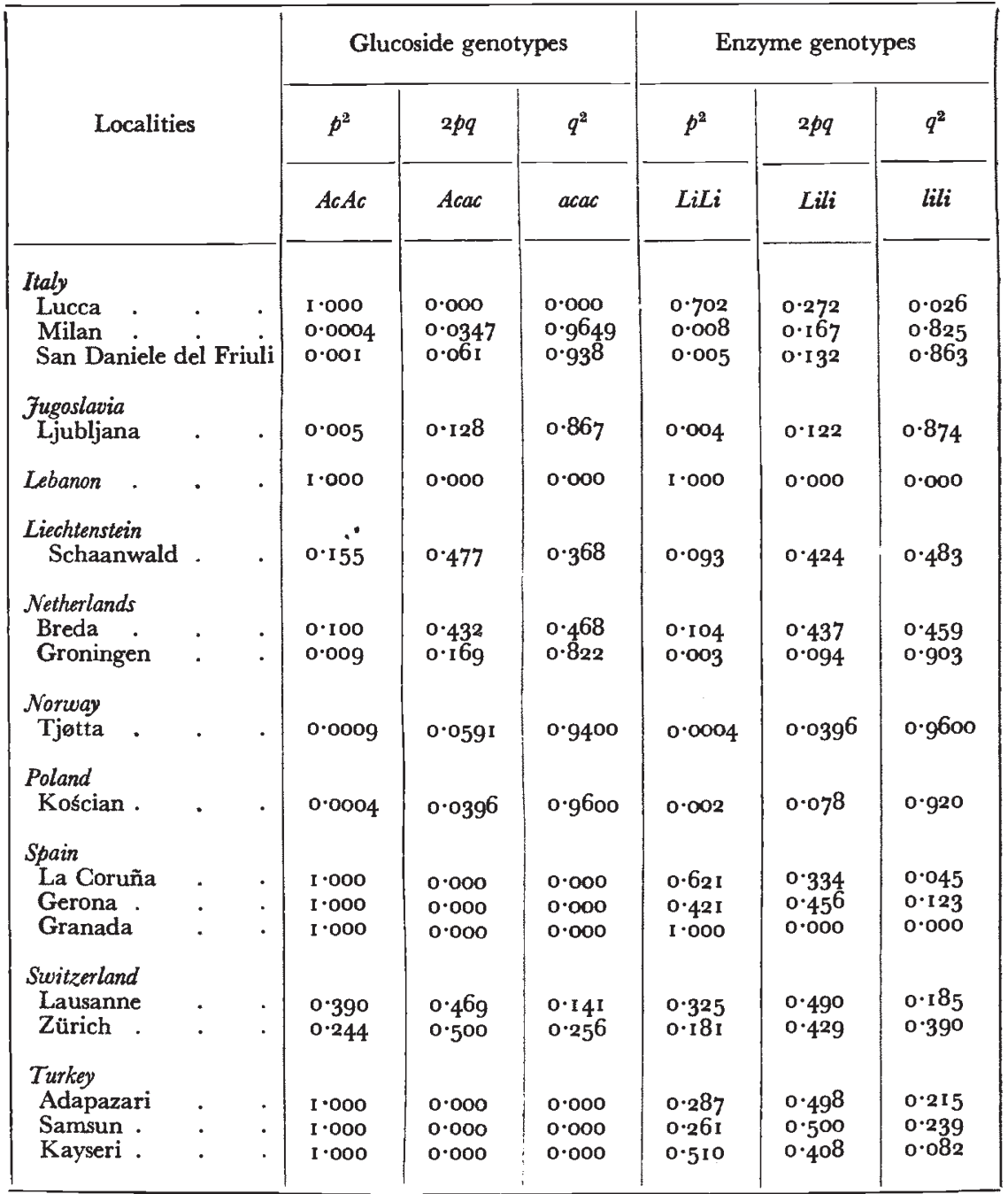


MELVILLE, J., COOP, I. E., DOAK, B. W., AND REIFER, I. I940. Cyanogenesis in white clover (Trifolium repens L.). IV. Methods of determination and general considerations. N.Z. F. Sci. Tech., 22, I 44 B-1 54 B.

MELVILLE, J., AND DOAK, B. W. I940. Cyanogenesis in white clover (Trifolium repens L.). II. Isolation of the glucosidal constituents. N.Z. J. Sci. Tech., 22, 67B-7IB.

MIRANDE, M. I912. Sur la présence de l'acide cyanhydrique dans le tréfle rampant (Trifolium repens L.). C.R. Acad. Sci. Paris, 155, 651-653.

RIGG, T., ASKEW, H. O., AND KIDSON, E. B. I933. Occurrence of cyanogenetic glucosides in Nelson pasture plants. N.Z. F. Sci. Tech., 15, 222-227.

TMOFEEFF-REssovskY, N. W. 1935. Ueber geographische Temperaturrassen bei Drosophila funebris. F. Arch. Naturgesch N.F., 4, 245-257.

WEINBERG, w. I908. Über den Nachweis der Vererbung beim Menschen. Verein Vaterländ. Naturk., Wurtemberg Jahresh., 64, 368-382.

WILliams, R. D. I939. Genetics of cyanogenesis in white clover. (Trifolium repens L.). 7. Genet., 38, 357-365. 